\title{
Kualitas Telur Puyuh Jepang (Coturnix coturnix japonica L.) Berdasarkan Variabel pH Telur, Kandungan Protein Telur dan Indeks Putih Telur setelah dilakukan Pencucian dan disimpan Selama Waktu Tertentu
}

\section{The Quality of Egg Japanese Quail (Coturnix coturnix japonica L.) based on Variable pH, Protein Content, and Albumin Index after Washing and Stored in Certain Time}

\author{
Muhammad Anwar Djaelani \\ Departemen Biologi Fakultas Sains dan Matematika Universitas Diponegoro \\ Jl, Prof. Soedarto, SH, Tembalang, Semarang \\ Email : muhammadanwardjaelani@ rocketmail.com
}

Diterima 4 November 2016/Disetujui 27 Januari 2017

\begin{abstract}
ABSTRAK
Puyuh Jepang (Coturnix coturnix japonica L.) banyak dibudidayakan untuk diambil telurnya karena produktivitas telur yang tinggi. Nilai gizi telur puyuh tidak kalah dengan telur unggas lain, sehingga dapat menambah variasi dalam penyediaan sumber protein hewani. Telur merupakan sumber protein hewani yang murah dan mudah untuk didapatkan oleh masyarakat Indonesia. Telur mengandung bahan organik yang mudah rusak. Salah satu faktor yang menyebabkan rusaknya telur adalah lama waktu penyimpanan . Penelitian ini bertujuan untuk menganalisis kualitas telur puyuh berdasarkan $\mathrm{pH}$ telur, kandungan protein telur dan Indeks Putih Telur setelah pencucian dan penyimpanan dalam waktu tertentu. Sampel yang digunakan adalah telur puyuh yang diambil pada hari ketiga setelah telur dikeluarkan dari induknya. Penelitian ini menggunakan rancangan acak lengkap dengan 5 kelompok perlakuan, masing-masing kelompok terdiri 10 ulangan. Kelompok tersebut adalah P1 kelompok telur,diamati pada hari ke 3. P2 kelompok telur tanpa pencucian, disimpan dan diamati pada harike 17. P3 kelompok telur dengan pencucian, disimpan dan diamati pada hari ke 17. P4 kelompok telur tanpa pencucian, disimpan dan diamati pada hari ke 31. P5 kelompok telur dengan pencucian, disimpan dan diamati padahari ke 31. Data dianalisis menggunakan Anova dan uji lanjut Duncan keduanya dengan taraf signifikansi 5\%. Hasil penelitian menunjukkan $\mathrm{pH}$ telur mengalami kenaikan, kandungan protein telur dan Indeks Putih Telur mengalami penurunan karena pencucian dan seiring dengan bertambahnya waktu penyimpanan . Penurunan kandungan protein telur dan Indeks Putih Telur dan kenaikan $\mathrm{pH}$ telur akibat dari lamanya penyimpanan dan pencucian yang menyebabkan perubahan kualitas telur.
\end{abstract}

Kata kunci : penyimpanan telur, protein telur, indeks putih telur, $\mathrm{pH}$ telur

\section{ABSTRACT}

Japanese Quails cultivated to be taken because of high egg productivity. The nutritional value of quail eggs are not inferior to other poultry eggs, which can add variation in the supply of animal protein sources. Eggs are a cheap source of animal protein and easy to obtain by the people of Indonesia. Eggs contain organic materials that can be easily damaged. One of the factors that led to the destruction of the eggs is long storage time. This study aimed to analyze the quality of quail eggs by $\mathrm{pH}$ eggs, the protein content of egg and egg white index after washing and storage within a specified time. The samples are quail eggs taken on the third day after the egg is removed from a parent. This study uses a completely randomized design with 5 treatment groups, each group comprised 10 replications. The group is a group P1 eggs, observed on day 3. P2 group of eggs without washing, kept and observed in harike 17. P3 group by washing eggs, stored and observed at day 17. The group P4 eggs without washing, kept and observed in day 31. P5 group of eggs by washing, kept and observed the day to 31. Data were analyzed using ANOVA and Duncan test both with significance level of 5\%. The results showed increased $\mathrm{pH}$ eggs, the protein content of eggs and Egg White index decreased due to leaching and with increasing storage time. A decrease in the protein content of eggs and Egg White Index and eggs $\mathrm{pH}$ rise due to the length of storage and leaching that causes changes in the quality of eggs.

Keywords : storage egg, protein content, albumin index, egg $\mathrm{pH}$ 


\section{PENDAHULUAN}

Puyuh merupakan salah satu jenis aves yang sudah banyak terdapat di Indonesia terutama strain Coturnix coturnix japonica L. Puyuh jepang (Coturnix coturnix japonica L.) memiliki sifat yang mudah didomestikasi dan mempunyai keunggulan terutama dalam kemampuan tumbuh dan berkembang biak secara cepat. Puyuh jenis ini dapat menghasilkan telur sebanyak 250-300 butir per ekor dalam kurun waktu satu tahun. (Nataamijaya, 2004). Nilai gizi telur puyuh tidak kalah dengan telur unggas lain, sehingga dapat menambah variasi dalam penyediaan sumber protein hewani. Secara umum, kandungan telur puyuh terdiri atas putih telur (albumen) 47,4\%, kuning telur (yolk) 31,9\%, dan kerabang serta membran kerabang 20,7\%. Kandungan protein telur puyuh sekitar $13,1 \%$, sedangkan kandungan lemak telur puyuh sekitar 11,1\% (Listyowati, 2009).

Telur segar yaitu telur yang baru diovoposisikan oleh induk mempunyai daya simpan pendek, jika dibiarkan dalam udara terbuka (suhu ruang) telur hanya mampu bertahan sekitar 10-14 hari. Telur akan mengalami perubahan ke arah kerusakan seperti terjadinya penguapan kadar air melalui pori kerabang telur yang berakibat berkurangnya berat telur, perubahan komposisi kimia, dan terjadinya pengenceran isi telur setelah waktu tersebut (Cornelia, dkk. 2014).

Telur yang dijual dipasaran tersimpan sekitar tujuh hari. Telur tersebut masih menunjukkan kualitas yang masih baik (Haryono, 2000).Hasil penelitian yang dilakukan oleh Fibrianti dkk. (2012) menunjukkan telur yang disimpan dalam suhu kamar selama 25 hari tanpa perlakuan apapun akan menurun kualitasnya. Lama penyimpanan menentukan kualitas telur, semakin lama telur disimpan, kualitas dan kesegaran telur semakin menurun (Haryoto, 2010).

Hasil penelitian yang dilakukan oleh Fibrianti dkk. (2012) menunjukkan bahwa telur ayam konsumsi yang dibersihkan dan tanpa dibersihkan berpengaruh sangat nyata $(\mathrm{p}<0,01)$ terhadap nilai IPT, IKT dan HU. Lama penyimpanan pada suhu kamar dari telur ayam konsumsi yang dibersihkan dan tanpa dibersihkan berpengaruh sangat nyata $(\mathrm{p}<0.01)$ terhadap nilai IPT, IKT dan HU.

Berdasarkan latar belakang di atas, perlu dilakukan penelitian yang bertujuan untuk menganalisis kualitas telur puyuh berdasarkan kandungan protein telur, Indeks Putih Telur dan $\mathrm{pH}$ telur setelah pencucian dan penyimpanan dalam waktu tertentu.

\section{METODE PENELITIAN}

Penelitian ini dilakukan di Laboratorium Biologi Struktur dan Fungsi Hewan Jurusan Biologi Fakultas Sains dan Matematika Universitas Diponegoro Semarang Penelitian ini menggunakan metode eksperimental dengan rancangan acak lengkap (RAL) (Hanafiah, 2001)

Sampel dalam penelitian ini adalah telur puyuh sebanyak 50 butir, yang berasal dari peternakan di Boyolali Jawa Tengah. Sampel yang digunakan diambil pada hari ketiga setelah telur dikeluarkan dari induknya. Digunakan Rancangan acak lengkap dengan 5 kelompok perlakuan, masing-masing kelompok terdiri 10 ulangan. Kelompok tersebut adalah :

- P1 kelompok telur,diamati pada hari ke 3.

- P2 kelompok telur tanpa pencucian, disimpan dan diamati pada hari ke 17.

- P3 kelompok telur dengan pencucian, disimpan dan diamati pada hari ke 17

- P4 kelompok telur tanpa pencucian, disimpan dan diamati pada hari ke 31 .

- P5 kelompok telur dengan pencucian, disimpan dan diamati pada hari ke 31 .

Variabel penelitian yang diamati adalah $\mathrm{pH}$ telur, kandungan protein telur dan Indeks Putih Telur. Indeks Putih Telur (IPT) merupakan hubungan antara tebal atau tinggi albumen telur dibanding dengan rata-rata dari panjang dan lebar putih telur. IPT digunakan sebagai salah satu dasar penentuan kualitas telur (Fibrianti, 2012). pH telur diukur dengan menggunakan $\mathrm{pH}$ meter

Kandungan protein telur dianalisis menggunakan metode Kjehdahl. Metode Kjedahl merupakan metode yang sederhana untuk penetapan nitrogen total pada asam amino, protein, dan senyawa yang mengandung nitrogen. Metode 
Kjehdahl digunakan untuk menganalisis kadar protein kasar dalam bahan makanan secara tidak langsung (Winarno, 2004).

Data hasil penelitian diuji dengan menggunakan Anova. Uji lanjut untuk mengetahui adanya perbedaan antar kelompok dilakukan dengan uji Duncan. Kedua uji dengan taraf signifikansi 5\%. ( Santosa, 2008).

\section{HASIL DAN PEMBAHASAN}

Kondisi lingkungan yang diamati selama penelitian yaitu meliputi suhu dan kelembaban relatif ruang penyimpanan. Secara keseluruhan adalah $27,5^{\circ} \mathrm{C}$ dan $71 \%$. Menurut BSN (2008) penyimpanan telur konsumsi yang ideal adalah pada suhu $27^{\circ} \mathrm{C}$ dengan kelembaban relatif $60 \%$. Suhu dan kelembaban relatif selama penyimpanan telur perlu untuk diketahui karena dua hal tersebut termasuk dalam faktor yang berperan dalam penurunan kualitas telur selama penyimpanan. Menurut USDA (2000) faktor faktor yang mempengaruhi penurunan kualitas telur adalah umur simpan, tekstur kerabang, suhu dan kelembaban relatif selama penyimpanan.

Hasil penelitian menunjukkan $\mathrm{pH}$ antar perlakuan dan antar waktu pengamatan berbeda nyata. Hasil penelitian kelompok perlakuan P1, P2 dan P5 menunjukkan semakin meningkat, dengan peningkatan secara statistik berbeda bermakna $(p<0,05)$. Hal ini menunjukkan bahwa semakin lama penyimpanan nilai $\mathrm{pH}$ Telur semakin meningkat. Penelitian Akyurek and Okur (2009) menunjukkan lama penyimpanan berakibat kenaikan $\mathrm{pH}$ putih telur dan kuning telur. Selama penyimpanan, $\mathrm{pH}$ telur menjadi semakin meningkat dari telur segar dengan $\mathrm{pH}$ berkisar 7,0 meningkat menjadi sekitar 8,0 setelah 2 minggu waktu penyimpanan dan meningkat menjadi 9,5 setelah 4 minggu waktu penyimpanan.

Tabel 1. Hasil analisis data Indeks Putih Telur, Kandungan protein dan bobot telur puyuh (Coturnix coturnix japonica L.) yang dilakukan pencucian sebelum disimpan selama waktu tertentu

\begin{tabular}{cccc}
\hline & $\mathrm{pH}$ telur & Protein telur & Indeks putih telur $^{\mathrm{a}}$ \\
\hline P1 & $7,00 \pm 0,02^{\mathrm{a}}$ & $13,10 \pm 0,005^{\mathrm{p}}$ & $0,077 \pm 0,0015^{\mathrm{k}}$ \\
P2 & $7,94 \pm 0,05^{\mathrm{b}}$ & $12,20 \pm 0,004^{\mathrm{q}}$ & $0,065 \pm 0,0021^{1}$ \\
P3 & $8,62 \pm 0,04^{\mathrm{c}}$ & $11,35 \pm 0,002^{\mathrm{r}}$ & $0,055 \pm 0,0024^{\mathrm{m}}$ \\
P4 & $9,38 \pm 0,01^{\mathrm{d}}$ & $10,65 \pm 0,005^{\mathrm{s}}$ & $0,034 \pm 0,0017^{\mathrm{n}}$ \\
P5 & $9,88 \pm 0,03^{\mathrm{e}}$ & $9,85 \pm 0,004^{\mathrm{t}}$ & $0,026 \pm 0,0020^{\circ}$ \\
\hline
\end{tabular}

Keterangan : angka yang diikuti superskrip yang berbeda pada kolom yang sama menunjukan hasil yang berbeda nyata $(\mathrm{P}<0,05)$.

Hasil penelitian antar kelompok perlakuan tanpa pencucian dan dengan pencucian yaitu antar kelompok P2, P3, P4 dan P5 berbeda bermakna $(p<0,05)$. Hal ini menunjukkan bahwa pencucian telur menyebabkan peningkatan $\mathrm{pH}$ Telur. Fibrianti dkk (2012) menyatakan pencucian menyebabkan pori kerabang telur terbuka akibat hilangnya selaput kutikula yang melapisi telur hilang karena pencucian. Menurut Jazil (2013), $\mathrm{CO}_{2}$ yang hilang melalui pori kerabang telur mengakibatkan konsentrasi ion bikarbonat dalam putih telur menurun dan merusak sistem buffer, sehingga menjadikan $\mathrm{pH}$ naik dan putih telur bersifat basa. Berdasarkan hal tersebut dapat dipahami bahwa lama waktu penyimpanan akan menyebabkan $\mathrm{pH}$ telur meningkat dan pencucian telur mempercepat peningkatan $\mathrm{pH}$ telur

Hasil penelitian menunjukkan kandungan protein telur antar perlakuan dan antar waktu pengamatan berbeda nyata. Hasil penelitian kelompok perlakuan P1, P2 dan P5 menunjukkan semakin menurun, dengan penurunan secara statistik berbeda bermakna $(\mathrm{p}<0,05)$. Hal ini menunjukkan bahwa semakin lama penyimpanan protein semakin menurun. Hasil penelitian antar kelompok perlakuan tanpa pencucian dan dengan pencucian yaitu 
antar kelompok P2, P3, P4 dan P5 berbeda bermakna $(p<0,05)$. Hal ini menunjukkan bahwa pencucian telur menyebabkan penurunan protein

Bell and Weaver (2002) Menyatakan lapisan kental putih telur mengandung protein dengan karakteristik gel yaitu ovomисуn. Menurut Jazil dkk. (2013) serabut ovoтисуn memberikan tekstur kental pada putih telur. Faikoh (2014) menyatakan kekentalan putih telur dipengaruhi oleh kandungan ovomucyn yang terdapat pada putih telur. Putih telur yang mengandung оvотисуn lebih sedikit akan lebih cepat mencair. Ikatan kompleks ovomucyn-lysozym terjadi karena peningkatan $\mathrm{pH}$. Ikatan tersebut menyebabkan air keluar sehingga putih telur menjadi encer. Berdasarkan hal tersebut dapat dipahami bahwa lama waktu penyimpanan akan menyebabkan protein menurun dan pencucian telur mempercepat penurunan protein.

Hasil penelitian menunjukkan Indeks Putih Telur antar perlakuan dan antar waktu pengamatan berbeda nyata. Hasil penelitian kelompok perlakuan P1, P2 dan P5 menunjukkan semakin menurun, dengan penurunan secara statistik berbeda bermakna $(p<0,05)$. Hal ini menunjukkan bahwa semakin lama penyimpanan nilai Indeks Putih Telur semakin menurun. Menurut Cornelia (2014) terjadi akibat adanya penguapan air dan gas seperti $\mathrm{CO}_{2}$ yang menyebabkan putih telur kental menjadi semakin encer. Menurut Siregar dkk. (2012), semakin lama penyimpanan atau umur telur mengakibatkan $\mathrm{pH}$ telur semakin meningkat. Peningkatan $\mathrm{pH}$ telur mengakibatkan adanya interaksi antara ovoтисin dan lysozime yang menyebabkan putih telur menjadi encer. Berdasarkan hal tersebut dapat dipahami bila semakin lama penyimpanan nilai Indeks Putih Telur semakin menurun.

Hasil penelitian antar kelompok perlakuan tanpa pencucian dan dengan pencucian yaitu antar kelompok P2, P3, P4 dan P5 berbeda bermakna $(p<0,05)$. Hal ini menunjukkan bahwa pencucian telur menyebabkan pernurunan Indeks Putih Telur. Berdasarkan data $\mathrm{pH}$ kelompok perlakuan tanpa pencucian, kelompok P3 lebih tinggi dari kelompok P2 dan kelompok P5 lebih tinggi dari kelompok P4, dapat diartikan bahwa pencucian telur menyebabkan peningkatan $\mathrm{pH}$ telur.

Berdasarkan hal tersebut dapat dipahami bila pencucian telur menyebabkan nilai Indeks Putih Telur menurun.

\section{KESIMPULAN}

Pada penelitian ini dapat disimpulkan bahwa pencucian sebelum telur puyuh disimpan serta lama waktu penyimpanan menyebabkan kualitas telur puyuh mengalami penurunan.

\section{DAFTAR PUSTAKA}

Akyurek, H. and A.A. Okur. 2009. Effect of Storage Time, Temperature and Hen Age on Egg Quality in FreeRange Layer Hens. Journal of Animal and Veterinary Advances 8 (10): 1953 1958

Bell, D. and Weaver. 2002. Commercial chicken meat and Egg. Kluwer Academic Publishers. United States of America.

Badan Standarisasi Nasional (BSN). 2008. SNI 3926:2008 Telur Ayam Konsumsi. BSN, Jakarta.

Cornelia, A., I. K. Suada, M. D. Rudyanto. 2014. Perbedaan Daya Simpan Telur Ayam Ras yang Dicelupkan dan Tanpa Dicelupkan Larutan Kulit Manggis. Indonesia Medicus Veterinus 3(2): 112-119.

Faikoh, N.E. 2014. Keajaiban Telur. Istana Media, Yogyakarta

Fibrianti, S.M., I. K. Suada, M. D. Rudyanto.2012.Kualitas Telur Ayam Konsumsiyang dibersihkan dan tanpa dibersihkan Selama Penyimpanan Suhu Kamar .Indonesia Medicus Veterinus 1(3):408-416.

Hanafiah, K.A. 2001. Rancangan Percobaan Teori dan Aplikasi. Raja Grafindo Persada, Jakarta. 
Haryono. 2000. Langkah-langkah Teknis Uji Kualitas Telur Konsumsi Ayam Ras Temu Teknis Fungsional non Peneliti. Balai Penelitian Ternak, Bogor.

Haryoto. 2010. Membuat Telur Asin. Kanisius. Yogyakarta.

Jazil, N., A. Hintono, S. Mulyani.2012.Penurunan Kualitas Telur Ayam Ras dengan Intensitas Warna coklat kerabang berbeda selama penyimpanan.Jurnal Aplikasi Teknologi Pangan 1(2): 43-47.

Listyowati, E. 2009. Tatalaksana Budidaya Puyuh Secara Komersial. Penebar Swadaya. Jakarta.

Muchtadi, T. R, Ayustaningwarno, F dan Sugiyono. 2010. Ilmu Pengetahuan Bahan Pangan. Penerbit Alfabeta. Bandung.

Nataamijaya, A. 2004. Fenotipe Reproduksi Dua Galur Puyuh Jepang (Coturnix coturnix japonica) pada Dua Suhu Ruangan Berbeda. JITV Vol 8 (4): 220-226.

North, M. O. and Bell, D. D. 1992. Commercial Chicken Production Manual. 4th Edition. An AVI Book Published by Van Nostrand Reinhold. New York.

Santoso, S. Panduan lengkap menguasai SPSS 16. 2008. Jakarta : PT Elex Media Komputindo, $237-248$.

Siregar R. F., A. Hintono dan S. Mulyani. 2012. Perubahan Sifat fungsional Telur Ayam Ras Pasca Pasteurisasi.J.Animal Agriculture , Vol. 1. (1) : p $521-528$

Tan, T. C., K. Kanyarat and M. E. Azhar. 2012. Evaluation of functional properties of egg white obtained from pasteurized shell egg as ingredient in angel food cake. International Food Research Journal, 19 (1): 303-308.

Umar, M.M., S. Sundari, dan A.M. Fuah. 2000. Kualitas Fisik Telur Ayam Kampung Segar di Pasar Tradisional, Swalayan dan Peternak di Kotamadya Bogor. Media Peternakan, Bogor.

United States Departement of Agriculture (USDA). 2000. gerading Manual
Agricultural Handbook number 75, Washington DC.

Winarno F, G. 2004. Kimia Pangan dan Gizi I. PT. Gramedia, Jakarta 